\title{
Verifikasi Data Estimasi Curah Hujan dari Satelit TRMIM dan Pos Pengamatan Hujan BMKG di Sulawesi Utara
}

\author{
Yosevina Nugrahenny Nugrohoa,b*, Ferdya, Wandayantolis ${ }^{b}$ \\ aJurusan Fisika, FMIPA, Unsrat, Manado \\ bBadan Meteorologi Klimatologi dan Geofisika
}

\begin{tabular}{l}
\hline K A T A K U N C I \\
\hline Curah hujan \\
AKurasi \\
Pos pengamatan \\
TRMM
\end{tabular}

\begin{tabular}{l}
\hline K E Y W O R D S \\
\hline Rainfall \\
Accuration \\
Conventional observation \\
TRMM
\end{tabular}

AVAILABLE ONLINE

25 Februari 2014

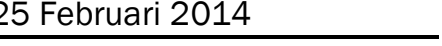

A B S T R A K
Telah dilakukan penelitian untuk mengetahui keakuratan data
estimasi curah hujan TRMM dan data curah hujan dari pos pengamatan
hujan BMKG untuk wilayah Sulawesi Utara. Data yang diolah merupakan
data bulanan dari tahun 2008 hingga 2012 . Data awal TRMM (bentuk
netCDF) sebelumnya diakses dengan menggunakan software GrADS
dengan menggunakan script tertentu. Kemudian pada tahap selanjutnya
digunakan software Microsoft Excel 2007 dalam pengolahan data serta
dalam menghitung uji t. Hasilnya menunjukkan bahwa data estimasi curah
hujan bulanan TRMM secara umum dapat digunakan pada wilayah
Sulawesi Utara, khususnya pada daerah yang belum terdapat penakar
hujan. Adapun kualitas data pos pengamatan hujan BMKG, terdapat $13 \%$
pos hujan dengan data yang tidak valid.
A B S T R A C T
A research aimed to calculated the accuration of TRMM rainfall
estimation data and rainfall conventional observation data of Meteorology
Climatology and Geophysics Agency for North Sulawesi had been done.
This research used monthly data from 2008 to 2012 . TRMM data is in
netCDF form that was accesed and processed by GrADS software using
certain script. Microsoft Excel software was used to calculate the data and
compute t test. The result showed that the TRMM monthly data can be
used in North Sulawesi generally. The data could be used also at the place
with no rainfall observation. There are $13 \%$ of total rainfall conventional
observation data with poor data quality.

\begin{abstract}
penakar hujan ini 60 pos pengamatan diantaranya memiliki kelengkapan data lima tahun atau lebih. Keseluruhan 60 pos pengamatan tersebut, enam titik merupakan stasiun BMKG. Adapun 54 pos pengamatan hujan lainnya merupakan pos hujan kerjasama yang ditempatkan pada unit kerja ataupun pada kantor pemerintah kota dan kabupaten. Pengamatan curah hujan pada enam titik stasiun BMKG diamati oleh para pengamat yang memiliki latar belakang pendidikan meteorologi, sedangkan untuk 54 pos pengamatan lainnya diamati oleh para pegawai dari pemerintah kota dan kabupaten serta masyarakat yang berada di sekitar wilayah tersebut yang sebelumnya telah diberikan
\end{abstract}

\footnotetext{
*Corresponding author: Jurusan Fisika FMIPA UNSRAT, Jl. Kampus Unsrat, Manado, Indonesia 95115; Email address: yosevina.nugroho@bmkg.go.id Published by FMIPA UNSRAT (2014)
} 
penyuluhan tentang bagaimana caranya mengukur curah hujan. Dengan kondisi demikian, maka BMKG tidak dapat memantau secara langsung bagaimana proses pengamatan yang dilaksanakan oleh pengamat dari pos hujan kerjasama sehingga keakuratan datanya pun dipertanyakan.

Pos hujan kerjasama ini sebagian besar terdapat di Sulawesi Utara bagian utara dan Sulawesi Utara bagian tengah, sedangkan untuk bagian selatan masih sedikit. Agar dapat memahami iklim dan cuaca serta menganalisisnya dibutuhkan data yang rapat serta akurat. Oleh karena itu, diperlukan acuan untuk mengetahui bagaimana kondisi curah hujan pada wilayah yang tidak terdapat pos hujan.

BMKG memiliki akses data untuk satelit TRMM (Tropical Rainfall Measuring Mission) di mana dari satelit ini didapat data estimasi curah hujan untuk titik mana saja yang diperlukan pada seluruh wilayah di Indonesia. Hal ini tentu sangat membantu, mengingat masih banyak wilayah di Indonesia khususnya Sulawesi Utara yang wilayahnya terpencil dan belum terdapat penakar hujan. Sebelum data TRMM ini dapat digunakan, diperlukan suatu verifikasi data terlebih dahulu. Verifikasi dilakukan dengan membandingkan data yang diperoleh dari TRMM dan data dari stasiun BMKG.

\section{Metode}

Data yang digunakan pada penelitian ini adalah data akumulasi curah hujan bulanan selama 5 tahun (2008 - 2013) untuk 60 pos di mana 6 pos tersebut berada pada stasiun BMKG dan 54 lainnya merupakan pos hujan kerjasama. Keenam pos yang berada pada stasiun BMKG diantaranya Stasiun Klimatologi Kayuwatu Manado, Stasiun Meteorologi Sam Ratulangi Manado, Stasiun Meterologi Bitung, Stasiun Geofisika Winangun, Stasiun Geofisika Tondano, dan Stasiun Meteorologi Naha. Pos pengamatan hujan lainnya (54 pos) yang merupakan pos hujan kerjasama ditempatkan pada daerah-daerah diantaranya Tuminting, Sindulang, Pandu, Aertembaga, Danowudu, Matuari, Kaaten, Tumatangtang, Tomohon Utara, Tomohon Barat, Langowan Utara, Kawangkoan, Tanawangko, Kombi, Pineleng, Kalasey, Sonder, Remboken, Tombulu, Tondano Selatan, Tompaso, Airmadidi, Likupang Barat, Wori, Tatelu, Kema I, Likupang Timur, Likupang Selatan, Tenga, Modoinding, Tumpaan, Tareran, Tompasobaru, Motoling, Tumpaan Popontolen, Ratahan, Tombatu, Touluaan, Poigar, Motabang Lolak, Lolak, Sangtombolang, Bolaang Timur, Pinolosian, Bolaang Uki, Pinolosian Timur, Pinolosian Tengah, Modayag, Kotabunan, MolobogNuangan, Tutuyan, Tahuna, Siau Tengah dan Tagulandang.

Alat yang digunakan dalam penelitian ini adalah: software GrADS v.2.0, dan Microsoft Office Excell 2007. Metode yang digunakan untuk mengetahui verifikasi dari data estimasi curah hujan satelit TRMM dan data curah hujan pos pengamatan hujan BMKG adalah dengan uji t. Digunakan $\alpha$ (taraf kesalahan) $=0.1 \%$ dan $\mathrm{dk}$ (derajat kebebasan) $=$ 118.

$$
\begin{array}{r}
t=\frac{\overline{X_{1}}-\overline{X_{2}}}{\sqrt{\frac{s_{1}^{2}}{n_{1}}+\frac{s_{2}^{2}}{n_{2}}}} \\
d k=n_{1}+n_{2}-2
\end{array}
$$

Perumusan hipotesis $\left(\mathrm{H}_{0}\right)$ dalam penulisan ini adalah sebagai berikut :

1. Tidak ada perbedaan antara data curah hujan dari stasiun BMKG dengan data curah hujan dari satelit TRMM.

2. Tidak ada perbedaan antara data curah hujan dari satelit TRMM dengan data curah hujan dari pos pengamatan hujan BMKG.

Ada dua verifikasi yaitu verifikasi data estimasi curah hujan satelit TRMM dan verifikasi data curah hujan pos pengamatan hujan BMKG. Ho diterima jika $t_{\text {tabel }} \leq t_{\text {hitung }} \leq \mathrm{t}_{\text {tabel }}$ (two tail test).

Diperhitungkan juga nilai RMSE (Root Mean Square Error) dalam hubungannya dengan verifikasi ini.

$$
R M S E=\sqrt{\frac{\sum_{i=1}^{n}\left(X_{o b s, i}-X_{m o d e l, i}\right)^{2}}{n}}
$$

Langkah-langkah kerja yang dilakukan pada penelitian ini adalah :

1. Data curah hujan bulanan selama 5 tahun (2008 - 2012) pada 60 pos pengamatan di Sulawesi Utara diambil di Stasiun Klimatologi Kayuwatu Manado (stasiun tempat pengumpul data).

2. Data estimasi curah hujan bulanan TRMM selama 5 tahun (2008-2012) didownload pada situs web http://mirador.gsfc.nasa.gov. Data ini merupakan jenis data nc.

3. Akses dan pengolahan data nc (data TRMM) menggunakan software GrADS, yang kemudian didapat data estimasi curah hujan.

4. Pengolahan data curah hujan dari pos pengamatan hujan, stasiun BMKG dan satelit TRMM selanjutnya menggunakan Microsoft Office Excel, termasuk didalamnya dalam pembuatan grafik, tabel dan perhitungan nilai t. Perhitungan nilai ini dengan menggunakan menu Data Analysis pada Microsoft Office Excel.

5. Nilai thitung kemudian dibandingkan dengan $t_{\text {tabel, }}$ tabel didapat 3,37 (nilai +3,37 dan -3,37). Nilai tabel dikonfimasi sesuai dengan taraf $\alpha=$ $0,1 \%$ dan $d k=118$. Apabila thitung berada diantara nilai ttabel maka Ho diterima, sebaliknya jika thitung lebih besar atau lebih kecil dari ttabel maka $\mathrm{H}_{0}$ ditolak. 
6. Analisis pada wilayah dengan $\mathrm{H}_{0}$ ditolak dan Ho diterima

7. Hasil analisis untuk menghasilkan kesimpulan

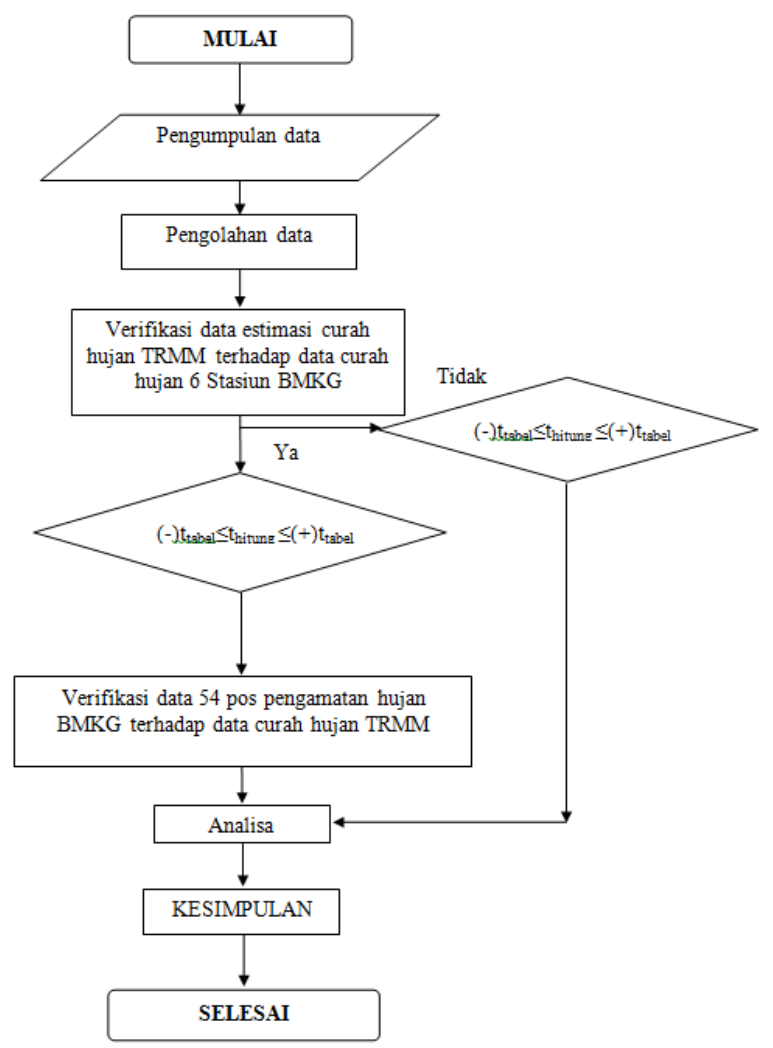

Gambar 1. Diagram alir penelitian.

\section{Hasil dan Pembahasan}

Pengujian hipotesa dengan uji t merupakan salah satu cara untuk memverifikasi suatu data terlebih untuk jenis data yang sama (data curah hujan). Verifikasi data estimasi curah hujan TRMM terhadap data curah hujan enam stasiun BMKG, ditentukan $\mathrm{H}_{0}$ : data curah hujan BMKG identik dengan data estimasi curah hujan TRMM, yang berarti bahwa tidak ada perbedaan yang signifikan antara data curah hujan dari stasiun BMKG dengan data curah hujan dari satelit TRMM sedangkan untuk $\mathrm{H}_{1}$ : data curah hujan BMKG tidak identik dengan data estimasi curah hujan TRMM, yang berarti bahwa ada perbedaan yang signifikan antara data curah hujan dari stasiun BMKG dengan data curah hujan dari satelit TRMM. Digunakan taraf kepercayaan 99,9\% dengan $\alpha=0,1 \%$ serta $d k=$ 118.

Lima dari enam stasiun BMKG didapatkan hasil $\mathrm{H}_{0}$ diterima, yang berarti data curah hujan stasiun BMKG identik dengan data estimasi curah hujan TRMM. Perhitungan TRMM identik dengan pengamatan langsung dari stasiun BMKG dikarenakan resolusi TRMM dengan daratan yang luas tidak menimbulkan bias yang berarti. Oleh karena itu, algoritma pada TRMM dapat menghitung curah hujan sesuai dengan kondisi jatuhan curah hujan yang sebenarnya terjadi. Pengamatan pada stasiun BMKG sendiri dapat dipercaya dan memiliki validitas yang tinggi sebab pengamatan dilakukan oleh orang-orang yang ahli dibidangnya serta diamati sesuai dengan prosedur yang berlaku, selain itu pengamatan hujan dilakukan setiap 3 jam sekali setiap hari serta penakar hujan (alat yang digunakan untuk mengukur curah hujan) ditempatkan pada area yang luas dan apabila ada kerusakan dapat segera diperbaiki oleh teknisi BMKG.

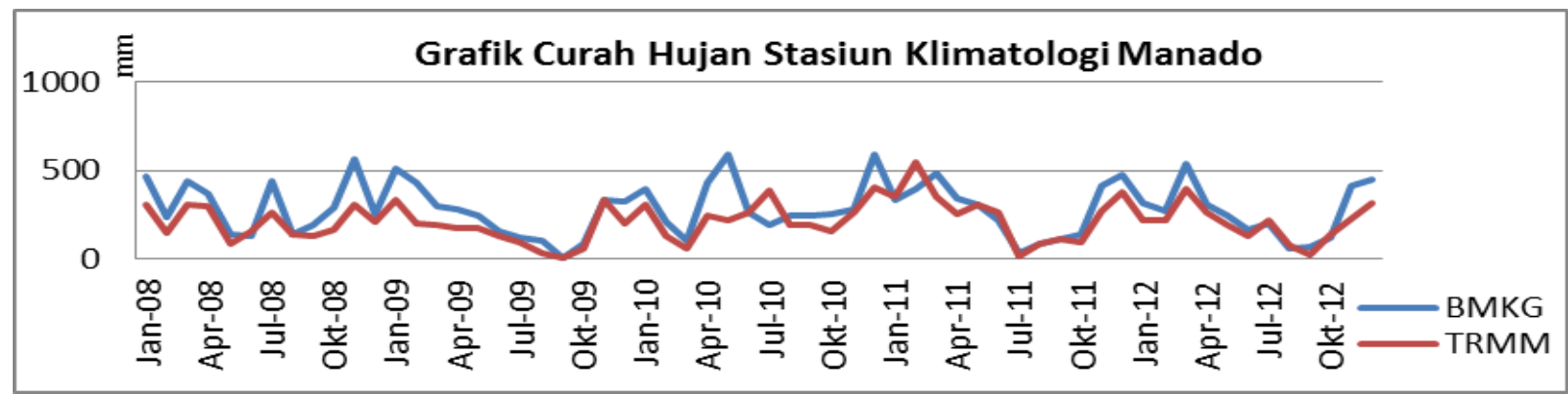

Gambar 2. Grafik Curah Hujan Stasiun Klimatologi Kayuwatu Manado terhadap Satelit TRMM.

Stasiun Meteorologi Naha merupakan stasiun yang data curah hujannya tidak identik dengan data estimasi curah hujan TRMM. Grafik curah hujan menunjukkan ada perbedaan yang cukup besar pada bulan-bulan tertentu (Gambar 3), serta didapat pula RMSE untuk wilayah ini adalah 21,06. Hal ini dapat dikarenakan oleh posisi geografis Stasiun Meteorologi Naha yang berada di wilayah kepulauan yang kecil yaitu di Kepulauan Sangihe, sehingga algoritma pada satelit TRMM belum mampu untuk menghitung dengan tepat pada wilayah tersebut.
Variabilitas cuaca yang diakibatkan faktor lautan berpengaruh sangat besar. Dibanding resolusi TRMM antara luas pulau terhadap lautan, menyebabkan bias yang besar antara pengamatan langsung dengan perhitungan TRMM. Dengan demikian karena data curah hujan yang berasal dari TRMM identik dengan 5 stasiun BMKG kecuali Stasiun Meteorologi Naha, maka data estimasi curah hujan TRMM dapat digunakan untuk analisis selanjutnya. 


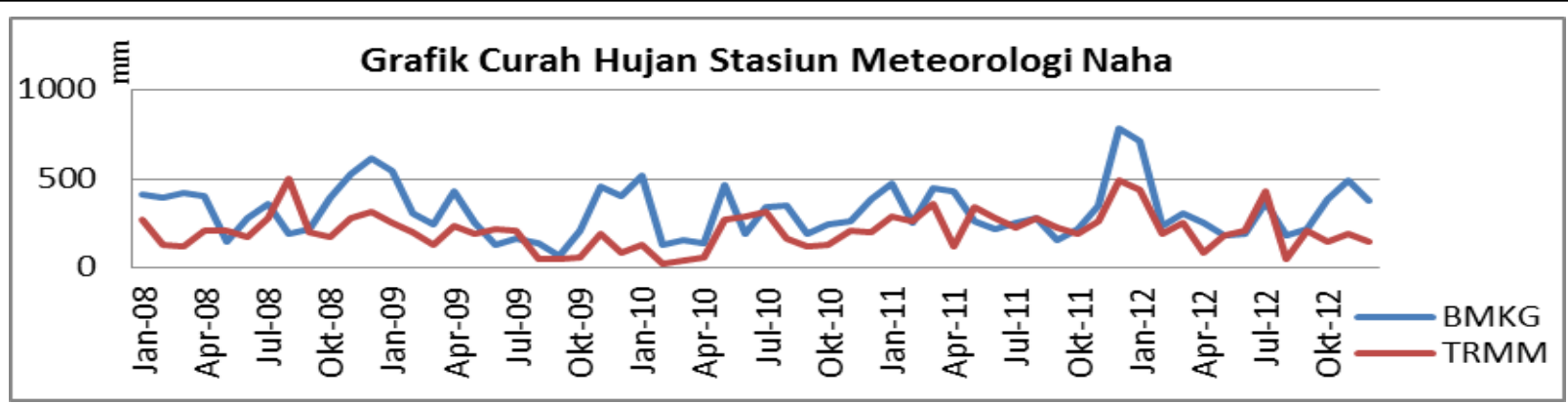

Gambar 3. Grafik Curah Hujan Stasiun Meteorologi Naha terhadap Satelit TRMM.

Verifikasi data curah hujan pos pengamatan hujan BMKG terhadap data estimasi curah hujan TRMM, ditentukan $\mathrm{H}_{0}$ : data estimasi curah hujan TRMM identik data curah hujan BMKG, yang berarti bahwa tidak ada perbedaan yang siginifikan antara data curah hujan dari satelit TRMM dengan data curah hujan dari pos pengamatan hujan BMKG sedangkan untuk $\mathrm{H} 1$ : data estimasi curah hujan TRMM tidak identik dengan data curah hujan BMKG, yang berarti bahwa ada perbedaan yang signifikan antara data curah hujan dari satelit TRMM dengan data curah hujan dari pos pengamatan hujan BMKG. Digunakan taraf kepercayaan 99,9\% dengan $\alpha=0,1$ $\%$ serta $\mathrm{dk}=118$.

Nilai thitung untuk 7 dari 54 pos pengamatan hujan BMKG tidak berada diantara nilai t tabel, yang berarti $\mathrm{H}_{0}$ ditolak yaitu pada pos hujan : Kema I, Tompasobaru, Motoling, Kotabunan, MolobogNuangan, Tutuyan, dan Tahuna. Adapun 7 pos hujan dengan $\mathrm{HO}$ ditolak artinya bahwa data curah hujan pada 7 pos hujan tersebut tidak identik dengan data curah hujan yang berasal dari TRMM. Mengacu pula pada pengujian sebelumnya bahwa data estimasi curah hujan TRMM identik dengan data curah hujan 5 stasiun BMKG ( $\mathrm{H}_{0}$ diterima) sehingga jika data curah hujan dari pos hujan kerjasama tidak identik dengan data estimasi curah hujan TRMM $\left(\mathrm{H}_{0}\right.$ ditolak) maka dapat dinyatakan bahwa data curah hujan dari pos hujan tersebut tidak valid. Hal ini berarti bahwa sebanyak $13 \%$ dari pos pengamatan BMKG yang data curah hujannya tidak valid.

Data pos pengamatan hujan yang tidak identik dengan data TRMM terjadi karena pengamatan pada pos-pos hujan tersebut tidak akurat. Menurut grafik curah hujan antara data pos pengamatan hujan Motoling dengan data satelit TRMM (Gambar 4), terjadi perbedaan data yang cukup signifikan dari bulan Mei 2010 hingga September 2012 dengan RMSE 16,99.

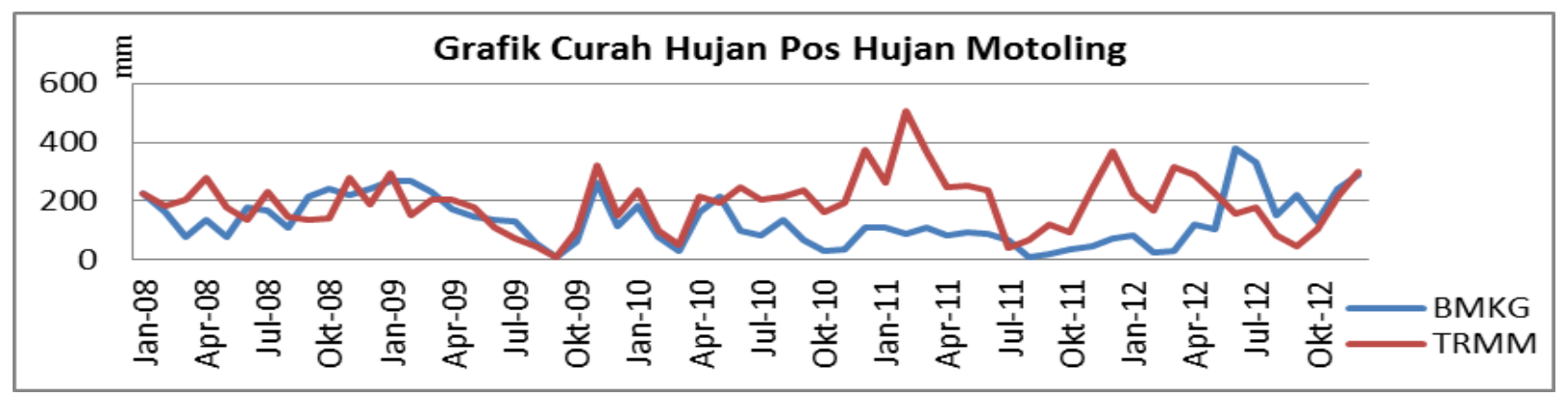

Gambar 4. Grafik Curah Hujan Pos Hujan Motoling terhadap Satelit TRMM.

Terdapat beberapa faktor yang menyebabkan data curah hujan pada pos pengamatan hujan tersebut tidak valid, diantaranya sebagai berikut :

1. Faktor alat (penakar hujan), yang meliputi :

- Kerusakan pada alat, misalnya terjadi kebocoran pada kran sehingga air hujan yang seharusnya tertampung menjadi terbuang karena kran tidak dapat menahan air.

- Penempatan alat yang tidak sesuai, misalnya alat diletakkan di bawah daerah tirisan (contohnya atap rumah), maka akumulasi air hujan yang tertampung pada atap rumah yang kemudian jatuh ke penakar hujan akan menjadi data yang tidak valid.

2. Faktor metode pengamatan, yang meliputi :
- Pengamatan yang seharusnya dilaksanakan setiap hari pukul 07.00 waktu setempat tidak dilaksanakan sebagaimana mestinya.

- Pengamatan dilakukan hanya pada hari kerja (Senin sampai Jumat) mengingat posisi alat, ada yang diletakkan di kantor pemerintah kabupaten dan kota, sehingga pengamatan pada hari libur diakumulasi ke hari kerja selanjutnya.

3. Faktor kesalahan manusia (human error), yang meliputi :

- Pengamat pos hujan kerjasama yang baru diganti sehingga belum mendapat pengetahuan yang cukup mengenai tata cara mengukur curah hujan.

- Alat diletakkan di tempat yang banyak anakanak sehingga alat tersebut menjadi bahan 
permainan seperti kran dibuka dan ditutup secara sembarangan.

Adapun pos hujan Tahuna terletak di wilayah Kepulauan Sangihe, mengingat letak geografisnya yang berada satu kepulauan dengan Stasiun Meteorologi Naha, maka data pada pos hujan ini menjadi tidak sama dengan data TRMM penyebabnya sama dengan Stasiun Meteorologi Naha, yaitu karena posisinya pada wilayah kepulauan yang kecil sehingga algoritma perhitungan pada satelit TRMM belum mampu dengan tepat untuk mendapatkan data curah hujan pada wilayah tersebut.

Terdapat $87 \%$ dari pos pengamatan hujan (sebanyak 47 pos) yang datanya valid. Hal ini berarti bahwa pada ke-47 pos pengamatan hujan tersebut pengukuran data curah hujannya sudah tepat, penempatan alatnya sudah sesuai serta prosedur pengamatannya sudah baik. Perhitungan data curah hujan pada satelit TRMM sudah sesuai dengan kondisi sebenarnya yang terjadi (diketahui dari pengukuran langsung dari pos pengamatan hujan BMKG).

\section{Kesimpulan}

Berdasarkan dua verifikasi yang telah diketahui maka didapat kesimpulan sebagai berikut :

1. Hasil verifikasi menunjukkan bahwa data estimasi curah hujan satelit TRMM secara umum identik dengan data curah hujan stasiun BMKG. Hal ini diketahui dari pengujian menggunakan uji $\mathrm{t}$, di mana dari 6 stasiun BMKG, 5 stasiun diantaranya $\mathrm{H}_{0}$ diterima, sehingga kelima stasiun tersebut data curah hujannya identik dengan data estimasi curah hujan TRMM.

2. Data curah hujan pada pos hujan kerjasama adalah data yang akurat yaitu sebanyak $87 \%$ pos pengamatan hujan, kecuali pada tujuh pos hujan yang disebabkan oleh faktor alat, metode pengamatan dan kesalahan manusia.

\section{Daftar Pustaka}

[1] As-syakur, A. R. 2011. Status of The TRMM Level 3 in Indonesia. In: Proceeding of The 2nd CReSOS International Symposium on South East Asia Environmental Problems and Satellite Remote Sensing; Denpasar, Bali-Indonesia, 2122 Februari 2011. HIm 140-142.

[2] Nasoetion, A. H dan Barizi. 1980. Metode Statistika Untuk Penarikan Kesimpulan. Penerbit PT Gramedia, Jakarta.

[3] Purwanto. 2011. Statistika untuk Penelitian. Pustaka Pelajar, Yogyakarta.

[4] Supranto, J. 1996. Statistik Teori dan Aplikasi. Edisi ke-5. Penerbit Erlangga, Jakarta.

[5] Tjasyono, B. H. K. 2006. Meteorologi Indonesia 1, Karakteristik dan Sirkulasi Atmosfer. BMG, Jakarta.

[6] Tjasyono, B. H. K. dan Sri Woro B. Harijono. 2007. Meteorologi Indonesia 2, Awan dan Hujan Monsun. BMG, Jakarta. 